\title{
Capital Market Operations and its Impacts on Local Investments in Nigeria
}

\author{
Suberu O. J., Aremu O. S., Afonja J. A. \\ Department of Banking\&Finance, The Polytechnic, Ibadan, U.I P.O Box 20258 Agbowo Area Ibadan, Ibadan, Oyo State. Nigeria
}

Email address:

un_va@yahoo.com (Suberu O. J.)

\section{To cite this article:}

Suberu O. J., Aremu O. S., Afonja J. A.. Capital Market Operations and its Impacts on Local Investments in Nigeria. International Journal of Economic Behavior and Organization. Vol. 3, No. 1, 2015, pp. 1-9. doi: 10.11648/j.ijebo.20150301.11

\begin{abstract}
This study examines the Nigerian capital market Operations, and its impact on Local investments in Nigeria aswith The main theoretical model, growth results from innovations that allow local sectors to catch up with frontier technology. In developing countries, catching up requires the cooperation of a foreign investor who is familiar with the frontier technology and a domestic entrepreneur who is familiar with local conditions, In such a country, domestic capital market matters for innovation, and therefore growth, because it enables the local entrepreneur to put equity into this cooperative venture (Philippe Aghion et al 2009)and to empirically analyze the impact of the capital market operations on local investment. In analyzing the impact, the time series of data cover the period of 1972 to 2011. Gross domestic Product is regressed on the Capital market variables (Market capitalization, Number of Dealings and All share indexes) to check the long run effect of capital market activities on the growth of the economy neoclassical growth model is use to explain the source of growth in the economy. The relevance of the capitalmarket in the encouragement of local investment and economic development were highlighted. The paper concludes with recommendation to stem up investors confidence and activities in the capital market so that it could contribute significantly to the growth of local investment in Nigeria.
\end{abstract}

Keywords: Financial Market, Local Investment, Financial Intermediation, Economic Growth, Capital Market, Innovations, Technology

\section{Introduction}

All long-run growth theories imply that a country can grow faster by investing more, in human or physical capital or in R\&D. A promising way forward is to integrate the capital market into a general macroeconomic framework following Blanchard (1981) and Gavin (1989). The BlanchardGavin model used a modified version of a conventional IS-LM framework. In the goods market it is assumed that total spending is influenced by the stock market value, current income, fiscal policy and the real exchange rate. It is assumed that the stock market value has a wealth effect and therefore influences consumption and determines the value of capital relative to its replacement costs. In the asset market, the model assumes no arbitrage between short-term bonds and shares such that share value is equated to return on bonds. The model is then analyzed for anticipated and unanticipated changes in monetary and fiscal policy assuming fixed and flexible prices. The analysis indicates that a stable set of fiscal policies play an important role in reducing volatility of real exchange rates and equity prices.

The capital market has been identified as an institution which contributes to the socio-economic growth and development of emerging and developed economies. This is made possible through some of the vital roles it play such as channeling resources, promoting reforms to modernize the financial intermediation capacity sector to link deficit to the surplus sector of the economy, mobilization and allocation of savings among competitive uses which are critical to local investment (Alile, 1984). It helps to channel capital or long-term resources to firms with relatively high and increasing productivity, thus enhancing economic expansion and growth (Alile, 1997).

Ekundayo (2002) argues that a nation requires a lot of local and foreign investments to attain sustainable economic growth and development. The capital market provides a means through which this is made possible. 
However, the paucity of long-term capital has posed a great challenge to economic development in most African countries including Nigeria.

Osaze (2000) sees the capital market as the driver of any economy to growth and development because it is essential for the long-term growth capital formation. It is crucial in the mobilization of savings and channeling of such savings to profitable self liquidating investment.

The Nigerian capital market provides the necessary lubricant that keeps turning the wheel of the economy. It does not only provide the funds required for investment but also efficiently allocates these funds to projects of best returns to fund owners. This locative function is critical in determining the overall growth of the economy. The functioning of the capital market affects liquidity, acquisition of information about firms, risk diversification, savings Mobilization and corporate control (Anyanwu, 1998). Therefore, by altering the quality of these services, the functioning of stock markets can alter the rate of local investment (Equakun, 20O5). Okereke-onyiuke (2000) posits that the cheap source of funds from the capital market remain a critical element in the sustainable development of the economy. She enumerated the advantages of capital market financing to include no short repayment period as funds are held for medium and long term period or in perpetuity, funds to state and local government without pressures and ample time to repay loans. The current clamor for local investment cannot therefore be overemphasized, and hence the relevance of this study at the crucial time.

Thus, efficient and liquid capital markets provide avenues for the effective utilization of funds for long-term investment purposes by mobilizing them from the surplus spending economic units to the deficit spending economic units (Ekineh, 1996). In short, an efficient capital market is essential for long-term growth in capital formation (Osaze, 2000). Osaze argues that a nation requires a lot of local and foreign investments to attain sustainable economic growth and development. The capital market provides a means through which this is made possible. In addition, capital markets provide the opportunities for the purchase and sale of existing securities among investors thereby encouraging the populace to invest in securities and fostering economic growth (Ewah, et al 2009). Therefore, efficiently functioning capital market affects liquidity, acquisition of information about firms, risk diversification, savings mobilization and corporate control. The successful operations of industrial sectors of any nation hinges on the efficiency of capital market, the potential and the possibility of translating into economic growth.

The first section of the study examines a general background of study and set out the significance objectives of the study. It also highlights the need for efficient capital market. The second section, gives the outlookof the past Literature and theory of economic growth. Section three will be on theoretical framework and methodology. Section four examines analyses of the finding. Section five conclusion and recommendations.

\section{Literature Review}

In 1986, Nigeria embraced the International Monetary Fund (IMF)World Bank Structural Adjustment Programme (SAP) which influenced the economic policies of the Nigerian government and led to reforms in the late 1980s and early 199Os. The programme was proposed as an economic psackage to rapidly and effectively transformed the Nigerian economy within two years (Yesufu 1996).

However, until SAP was abandoned in 1994, the objectives were not achieved due to the inability of government to judiciously implement some of its policy measures (Oyefusi and Mogbolu, 2003).

The notable reforms include monetary and fiscal policies, sectoral reforms such as removal of oil subsidy in 1988 to the tune of $80 \%$, interest deregulation from August 1987, financial market reform and public sector. There have been growing concerns and controversies on the role of the Stock markets on local investment (Oyejide, 1994).

Levine and Zervos (1996) examine whether or not there was a strong empirical relationship between stock market development and long-run economic growth. They found a strong correlation between overall stock market development and long-run economic growth.

Demiurgic-Kunt and Levine (1996) found that different measures of stock exchange size are strongly correlated to other indicators of activity levels of financial, Banking, Nonbanking institutions as well as to insurance companies and pension funds. They concluded that countries with welldeveloped stock markets tend to also have well-developed Financial intermediaries. Again, Demiurgic-Kunt and Maksimovic (1998) have shown and re-emphasized the complementary role of the stock market and banks that they were not rival or alternative institutions.

The rate of Gross Domestic Product (GDP) per capita was regressed on a variety of variables designed to control political instability, investment in human capital and macroeconomic condition and then, included the conglomerated index of stock market development.

They found empirically that the measures of stock market liquidity were strongly related to growth, capital accumulation and productivity while stock market size did not seems to correlate with increased local investment.

Of late there was a growing concern on the role of stock market in economic growth, Levine and Sara (1996); Demirguc-Kunt and Roos (1996); Oyejide (1994); Nyong (1997); Obadan (1998); Onosode (1998); Emenuga (1998); Osinubi (1998), The stock market is the focus of economists and policy makers because of the perceived benefit it provides for the economy. The stock market provides the fulcrum for capital market activities and it is often cited as a barometer of business direction. An active stock market may be relied upon to measure economic activities using the stocks market index (Obadan, 1998). 
Stock market contributes to economic growth through the specific service it performs either directly or indirectly. Notable among the functions of the stock market are mobilization of savings,creation of liquidity, risk diversification, improve dissemination and acquisition of information, and enhanced incentive for corporate control, improving the efficiency and effectiveness of these function, through prompt delivery of their services, can increase the rate of economic growth (Oloyede, 2001).

At any stage of a nation's development both the government and the private sectors would require long-term capital. For instance, companies would need to build new factories, expand existing ones, or buy new machinery.

Government would also require funds for the provision of infrastructures. All these activities require long-term capital, which is provided by a well functioning stock market (Olowe, 1997).

The economic significance of the relationship between stock market development and growth vary according to a country's level of economic development with a larger impact in less developed economies Filler et al. (1999).

The proponent of positive relationship between stock market development and economic growth hinged their argument on the fact that the stock market aids economic growth and development through the mobilization and allocation of saving; risk diversification, liquidity creating ability and corporate governance improvement among others.

Nyong (1997) report, as far back as 1999, Goldsmith Raymond observed that the emergence of equity markets and its rapid development indicate the level of economic growth and development.

Hussian et al. (2001) opined that there are two perspectives to stock market, the recipient perspective and the policy maker's perspective. From the perspective of the recipient LDS, private portfolio flows in local stock and bond markets are potentially welcome vehicle for raising capital for domestic firms. Well functioning local stock and short-term bond markets also help domestic investors to diversify their assets (an option usually open to the wealthy) and can act to improve the efficiency of the whole financial sector by serving as a screening and monitoring device for allocating funds to industries and firms with highest potential returns.

Michael and Stephen (2003) summarized that, although private portfolio/ financial flows rose and fell dramatically in the 1990 s, they were based largely on a mythical belief that free market and perception of a sound currency would automatically guarantee rapid economic growth. However, their inherent volatility and the fact that the market responds primarily to global interest-rate differentials, as well as to investors of practical and economic stability, make the stock market a very tenuous foundation on which to base medium or long-term development strategies.

The recent global economy and financial crisis made the then British Prime Minister (Mr. Gordon Brown) to put up huge sums of money and standing ready to recapitalize and take equity stakes inbanks. A staggering total sum E1, 873 billion ( $\$ 2,556$ billion) was agreed for this purpose in the euro area alone. (Business Day,2008).

The French, bailed out just one, Dixie, a small FrancoBelgian lender, it is use as a precautionary measure, and this had made most French banks to be able to absorb the huge losses they have made on sub-prime loans in America. The household savings rate remains high, yet concerns were on the economy. Third-quarter GDP figures are likely to show that the French economy is already in recession (ibid). The IMF forecast growth of 0.2 percent in the year 2009; this made economist to oppose this, because recently it was discovered that unemployment is on the increase, this is backed up with the announcement of a 4,000 job cut in France by a carmaker company, Renault (ibid). The present financial crisis had made Asia government to take measures to allay disquiet. In China the Stock market has lost twothirds of its value since last October; the property market is wobbling and growth is slowing, this trends all predated the latest panic, but Asia government had being making move to restore confidence in the minds of investor reviving the stock market by abolishing a tax on share - buying and investing in the market itself. (Google)

The crisis presently appears not to have largely affected the Nigeria market, but the little effect may be devastating because of the low risk absorption capacity of the operating companies. The continuous crash in the price of stock on the floor of the Nigerian Stock Exchange attests to this. And to guard against this, the Insurance Companies must take the issue of pricing more seriously if they wish to remain in business in the years ahead. (ibid) Experts concluded that the crisis though for now had little effect on the local market, but it will affect the value of crude oil in world market which will directly affect the local market on the long run. (ibid). Nigeria Financial system is stronger now especially with the successful completion of the banking sector consolidation before the current global financial crisis started. Capital inflow has remained very strong. Currently, it stands at $\$ 8.5$ billion as at the end of August 2008, compared with $\$ 5.8$ billion in 2005. The Central Bank of Nigeria has reviewed what is currently going on globally with respect to the Nigerian economy. The conclusion of Nigerian economists, financial experts and $\mathrm{CBN}$ governor after the meeting of the Monetary Policy Committee, is that the Nigerian economy is safe and robust, (Business Day, 2008).

\section{The Financial Market}

The international financial market over the world has grown very fast in the recent years. The private capital market is consistently improving since 1997. The buoyant capital flows among the nation boundaries have raised the existing strength of the financial market domestically as well as internationally. The markets over the world, particularly the financial markets are largely affected by the hedge funds. The use of hedge funds has allowed the trading activities with large number of dealers. Traditionally the banks were involved in the activities of lending and receiving deposits. In 
the recent years banking sector among the countries over the world are the main area of concerns in the financial activities with rendition of a large number of services. Banking sector has a major role in developing the financial sector in the rural areas with the result of falling transaction cost on investment.

The financial markets can be majorly divided into money and capital market. Money markets are Markets for borrowing and lending money for three years or less. The securities in a money market can be government bonds, Treasury bills and commercial paper from banks and companies. The money market is not a place. It is the continual buying and selling of short-term liquid investments, trading in highly liquid short-term assets and securities, such as Treasury bills and commercial paper. The money market is often, though not always, included in counts of the money supply. One may trade on the money market either on an exchange or over-thecounter.

The capital Market on the other hand is a market where both government and companies raise long term funds to trade securities on the bond and the stock market. It consists of both the primary market where new issues are distributed among investors, and the secondary markets where already existing securities are traded. In the capital market, mortgages, bonds, equities and other such investment funds are traded. The capital market also facilitates the procedure whereby investors with excess funds can channel them to investors in deficit. The capital market provides both overnight and long term funds and uses financial instruments with long maturity periods.

The following financial instruments traded in this market includes

- Foreign exchange instruments, equity insurance, Credit market derivatives and hybrid instruments.

\section{Historical Background of the Nigeria Stock Exchange}

The Nigerian Stock Exchange (NSE) was formed in 1960 and was known as the Lagos Stock Exchange. In December 1977, the name was changed to The Nigerian Stock Exchange. Currently, The Nigerian Stock Exchange (NSE) consists of six branches and the Head Office is in Lagos, but has an office in Abuja. The Trading System of the NSE is fully automated. The Nigerian Stock Exchange commenced operations in1961 with 19 securities enrolled for trading but at present, the numbers of enrolled securities is 282. The Lagos branch was launched in 1961; Kaduna, 1978; Port Harcourt, 1980; Kano, 1989; Onitsha, February 1990; and Ibadan August 1990; Abuja, October 1999 and Yola April 2002. In 1988, The Nigerian Stock Exchange management protested to the government about a report on the reform of Nigeria's capital market.

The capital market is the cornerstone of every financial system since it provides the funds needed for financing not only business and other economic institutions, but also the programme of government as whole. The capital market is essentially a market for long term securities that is stock, debenture and bonds lasting for usually longer than three years. The proper functioning of the capital market was not set up until the establishment of the Central Bank in 1959 and launching of the Lagos stock exchange in 1961even though securities were floated as far back as 1946. The needs to have an organized stock exchange came up and committee was set up by the government under the chairmanship of Prof. R.W.Barbock to consider the feasibility of having indigenous forum for the purchase and sales of shares and stocks.

The Nigerian security and exchange commission (NSEC) is the apex institution for the regulation and monitoring of the Nigeria capital market. The commission was established under the security and exchange commission decree 1979, operating retrospectively from 1 st April 1978. Prior to the SEC, two bodies had in succession been responsible for the monitoring of capital market activities in Nigeria. The first was capital issues committee, which operated between 1962 and 1972. It could not be seen as the superintendent of the capital market because its functions were more or less advisory without the force of instruction even through its functions included the coordination of capital market activities. The next body was the capital market issues commission (CIC) which came into being in March 1973. The C.I.C, unlike its predecessor, had full powers to determine the price, timing and volume of security to be issued. Despite this wider power, the CIC could not be seen as the apex of capital market because it concerned itself with public companies alone and its activities did not cover the stock exchange and government securities. The enabling Act of the Securities and Exchange Commission specifies its overriding objectives as investors' protection and development while its functions were divided into two regulatory and development. The functions of the commission are extensively spelt out in Nigeria Securities and Exchange Commission Decree (Decree No 29) of 1983 and the Nigerian Enterprises Promotion Decree 1990. According to section (6) subsection (9) to (10) the commission is charged with the following duties and functions among others.

- Determining the amount of price and time when securities of companies are to be sold to the public whether through offer for sale or subscription.

- Registering all securities proposed to be offered for sale to or for subscription by the public. The Nigerian Stock Exchange As one of the constituencies of the capital market, the exchange is a private, non-profit making organization, limited by guarantee.

- It was incorporated via the inspiration and support of businessmen and the federal government. Own by about 300 members. The membership includes financial institution, stockbrokers and individual Nigerians of high integrity, who have contributed to the development of the stock market and Nigerian economy. The Nigerian stock exchange started with the incorporation of the then Lagos stock exchange in 1960. Trading 
commenced on the exchange in 1961 after the enactment of the Lagos stock exchange Act of 1961, the self regulatory organization was subsequently reorganized and renamed the Nigerian stock exchange 1977, based on the report and recommendation of Pius Okigbo financial system review commission. The stock exchange is thus an institution of capital market, which provides trading floors where all dealing members operates on every business day. The exchange now has nine (9) branches and all the branches function principally as trading floor.

\section{The Importance of the Capital Market to the Development of the Nigerian Economy}

According to Al-Faki (2006), the capital market is a network of specialized financial institutions, series of mechanisms, processes and infrastructure that, in various ways, facilitate the bringing together of suppliers and users of medium to long term capital for investment in socioeconomic developmental projects". The capital market is divided into the primary and the secondary market. The primary market or the new issues market provides the avenue through which government and corporate bodies raise fresh funds through the issuance of securities which is subscribed to by the general public or a selected group of investors. The secondary market provides an avenue for sale and purchase of existing securities.

Sule and Momoh (2009) found that the secondary market activities have impacted more on Nigeria per capita income by tending to grow stock market earnings through wealth than the primary market. The roles of the capital market in the development of the economy include:

(1) It provides opportunities for companies to borrow funds needed for long-term investment purposes.

(2) It provides avenue for the marketing of shares and other securities in order to raise fresh funds for expansion of operations leading to increase in output/production.

(3) It provides a means of allocating the nations real and financial resources between various industries and companies Through the capital formation and allocation mechanism the capital market ensures an efficient and effective distribution of the scarce resources for the optimal benefit to the economy.

(4) It reduces the over reliance of the corporate sector on short term financing for long term projects and also provides opportunities for government to finance projects aimed at providing essential amenities for local investors.

(5) The capital market can aid the government in its privatization programme by offering her shares in the public enterprises to members of the public through the stock exchange.

(6) The capital market also encourages the inflow of foreign capital when foreign companies or investors invest in domestic securities, provides needed seed money for creative capital development and acts as a reliable medium for broadening the ownership base of family-owned and dominated firms.

\section{Methodology of the Study}

\subsection{Model Specification}

Stock market and economic growth has been canter of discussion in development literature, Samuel (1996); Demirguc-Kunt and Roos (1996);Akinifesi (1987); (Levine and Sara, 1996); Obadan (1998); Onosode (1998); Emenuga (1998); (Osinubi, 1998).

The study adopts the neoclassical growth model to explain the source of growth in the economy. The equation is written in general aggregate production function. This approach has got a wide application in econometric analysis for example, Akinlo and Ayodele F. Odusola. (2000); Levine and Sara (1996); Obstfeld (1994) and is adopted from study of Owolabi A and Ajayi N. O (2013) with little modification.

Using a production function approach, it states that the growth rate of output (GNP) is principally determined by the following factors:-

The rate of growth of gross labour multiplied by the labour income share.

The rate of growth of gross capital input multiplied by the capital income share; and

Change in technology.

Thus, this is given as:

$$
\mathrm{g}=\mathrm{f}(\mathrm{L}, \mathrm{K}, \mathrm{T})
$$

$$
\begin{aligned}
& \mathrm{g}=\text { Growth of GDP } \\
& \mathrm{L}=\text { Labour } \\
& \mathrm{K}=\text { Capital formation/Investment } \\
& \mathrm{T}=\text { Technology }
\end{aligned}
$$

The application of this method, however, has been extended to incorporate other determinants of economic activities such as, financial sector development (proxied by stock market development index), debt overhang, state of political stability (proxied), foreign direct investment, cross capital formation; and country, policy dummies, for example, Collier and Gunning (1998), DemirgucKunt and Roos (1996), (Emenuga, 1998), (Filler et al., 1999).

Specification of the model is specified thus:

$$
\mathrm{G}=\mathrm{f}(\mathrm{gcf}, \mathrm{fdi}, \mathrm{cmi}, \mathrm{doh})
$$

where;

$\mathrm{G}=$ growth of GDP

Gcf = gross capital formation

$\mathrm{Fdi}=$ foreign direct investment

$\mathrm{Cmi}=$ capital market index

Doh $=$ debt overhang.

The estimated form of the model is as given below

$$
\mathrm{G}=\mathrm{a}+\operatorname{bigcf}+\mathrm{b} 2 \mathrm{fdi}+\mathrm{b} 3 \mathrm{cmi}+\mathrm{b} 4 \mathrm{doh}+\mathrm{u}
$$

where 
$\mathrm{Uti}=$ error term. $\mathrm{E}$

\subsection{Estimation Technique}

Regression analysis of the ordinary least square is use in this study to test the relationship between the stock market and economic growth measured by the numbers of independent variables offers by the markets, which are gross capital formation (public investment), foreign direct investment, capital market index (Proxied by growth of market capitalization) debt overhang, proxied by export minus GDP ratio. This study focuses on the Nigeria stock market between the periods of 1972 to 2011 (period of 40 years).
Equation (iii) will be estimated using ordinary lease squares technique (OLS). The equation will also be subjected to a dynamic estimation, using the lagged structure of the variables.

\subsection{Sources of Data}

Secondary data are used in this study. The data were collected from the Nigerian Stock Exchange (NSE), Fact Books, Security and Exchange Commission (SEC), Market Bulletins, Central Bank of Nigerian (CBN) statistical bulletins and Federal Office of Statistics, Statistical Bulletin.. The data are empirically analyzed and results are discussed, data covering the period of $1972-2011$.

\section{Discussion of Findings}

Table 1. Shows results of data obtained from NSE gross capital formation (public investment), foreign direct investment, capital market index (Proxied by growth of market capitalization) debt overhang, proxied by export minus GDP from 1972 to 2011 (period of 40 years).

\begin{tabular}{|c|c|c|c|c|c|c|c|c|c|c|}
\hline Model & $\mathbf{R}$ & $\mathbf{R}^{2}$ & AdjustedR $^{2}$ & $\begin{array}{l}\text { Std. Error of the } \\
\text { Estimate }\end{array}$ & Change St & tics & & & & $\begin{array}{l}\text { Durbin- } \\
\text { Watson }\end{array}$ \\
\hline & & & & & $\mathrm{R}^{2}$ Change & F. Change & df1 & df2 & Sin. F Change & \\
\hline 1 & $.996^{\mathrm{a}}$ & .978 & .967 & 541268.7674 & .978 & 200.600 & 4 & 30 & .000 & 1661 \\
\hline
\end{tabular}

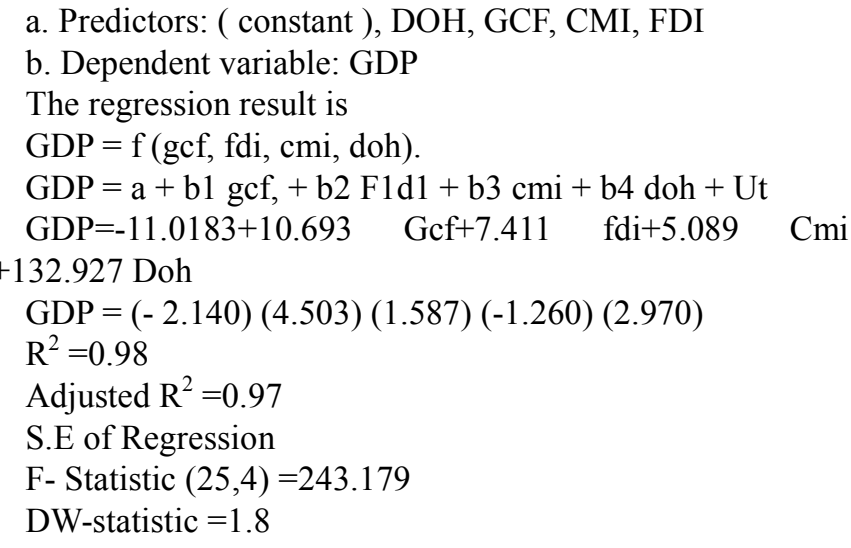

\subsection{Findings}

From the result so far, it is obvious clear that the variables in the model were highly correlated and have a significant impact on growth rate of gdp. The estimated model is a good one with desirable characteristics and the impact of capital formation on economic growth and development has been established to depend on the trends in variables such as gdp, gcf,cmi, and doh. It can also be concluded from the result that there is significant impact on the gcf and gfc (gross capital formation) while there is significant impact between gdp and fdi (foreign direct investment) at .125 percent level of significant. There is also a significant impact on gdp and cmi (capital market index) at .219 percent level of significance. The last variable which is doh (debt overhang) has very low level of significant impact on gdp. It is at .006 percent level of significance (Owolabi A and Ajayi N.O 2013) and capital market in Nigeria has the potentials for growth inducing but has not contributed meaningfully to the economic growth of Nigeria due to low market capitalization, small market size, few listed companies, low volume of transactions, low absorptive capitalization, illiquidity etc. Also our result supports Demirgue Kunt and Asli (1996) and Harris(1997) who found hard evidence and strong positive relationship between stock market and increased local investment. It was also gathered that the capital market allows many Nigerians to invest their excess cash in the stock exchange thereby leading to economic growth of the country.

\subsection{Conclusion}

Findings shows that the capital market impact on economic growth via market capitalization, market index, value of transaction and total listing of equity and government stock. As it was observed market capitalization, government stock and value of transaction are important capital market variables that are capable of influencing economic growth. Hence the capital market remain one of the mainstream in every economy that has the power to influence or impact economic growth therefore the organized private sector is to invest in it. The market capitalization have not impact significantly on the GDP while volume of transaction and total listed equities and Government stock have significant impact on the GDP. The government is therefore advised to put up measures to stem up investors' confidence and activities in the market and more foreign investors should be encouraged to participate in the market for improvement in the declining market capitalization so that it could contribute significantly to the Nigerian economic growth. (Atoyebi Kehinde .O. et al. 2013)

\section{Recommendations}

1. In order for the Nigerian capital market to be a pivotal force in Nigeria socio-economic growth and development and encouragement of local investment, the following suggestions are put forward: 1.First, improvement in the declining market 
capitalization by encouraging more foreign investors to participate in the market, maintain state of the art technology like automated trading and settlement practices, electronic fund clearance and eliminate physical transfer of shares.

2. There is also need to restore confidence to the market by regulatory authorities through ensuring transparency and fair trading transactions and dealings in the stock exchange. It must also address the reported cases of abuses and sharp practices by some companies in the market.

3. Moreover, the total listing in the NSE is still a far cry compared to other stock exchanges like South Africa and Egypt. Therefore, to increase the number of listed companies there is need to ensure stable macroeconomic environment, encourage both local and foreign multinational companies (MNCs) or their subsidiaries to be listed on the Nigerian Stock Exchange, relax the listing requirements to the first tier market and ensure tax rationalization in the capital market to encourage quotation and public interest in shareholdings. For new issues, increase the minimum equity capital requirements for companies other than banks, insurance companies and other financial institutions, encourage merger and consolidation, discriminatory income tax in favour of public quoted companies and aggressive enlightenment programme to increase awareness of the benefits of investing in the stock market and seeking quotation at the stock exchange.

4. Lastly, to boost the value of transactions in the Nigerian capital market, there is need for availability of more investment instruments such as derivatives, convertibles, futures, swaps, options in the market. From the forgoing, it is seen that the Nigeria Capital Market can no doubt stimulate local investment in Nigeria if the recommendations given above are looked into and meticulously implemented by the authority of the Nigeria Stock Exchange, who midwifes the Nigeria Capital market.

Table 2. Showcase the Data used for the period of 40 years

\begin{tabular}{|c|c|c|c|c|c|c|}
\hline $\mathbf{S} / \mathbf{N}$ & YEAR & $\begin{array}{l}\text { GDP Nominal ADP N } \\
\text { Billon }\end{array}$ & $\begin{array}{l}\text { GCF(Gross Capital } \\
\text { Formation) N Billon }\end{array}$ & $\begin{array}{l}\text { FDI (Foreign Direct } \\
\text { Investment) N Billon }\end{array}$ & $\begin{array}{l}\text { Capital Market } \\
\text { Index N Billon }\end{array}$ & D.O.H\% \\
\hline 1 & 1972 & $10,784.2$ & 961.3 & $1,589.4$ & 461.2 & 101.00 \\
\hline 2 & 1973 & $11,341.3$ & $5,388.5$ & $1,901.2$ & $1,586.8$ & 88.00 \\
\hline 3 & 1974 & $22,559.5$ & $4,927.8$ & $1,998.5$ & $1,137.1$ & 97.00 \\
\hline 4 & 1975 & $21,558.8$ & $5,019.8$ & $2,009.5$ & $1,815.2$ & 100.00 \\
\hline 5 & 1976 & $27,297.5$ & $8,107.3$ & $2,081.1$ & $2,255.2$ & 220.00 \\
\hline 6 & 1977 & $32,747.3$ & 942.6 & $2,801.4$ & $2,592.8$ & 415.00 \\
\hline 7 & 1978 & $36,083.6$ & $9,386.3$ & $2,941.7$ & $5,009.7$ & 213.00 \\
\hline 8 & 1979 & $43,150.8$ & $9,074.5$ & $35,131.1$ & $4,161.8$ & 265.00 \\
\hline 9 & 1980 & $50,848.6$ & $10,841.2$ & $3,620.1$ & $5,709.9$ & 219.00 \\
\hline 10 & 1981 & $50,749.1$ & $12,215.0$ & $3,757.9$ & $6,562.6$ & 159.00 \\
\hline 11 & 1982 & $51,709.2$ & $12,215.0$ & $5,382.8$ & $7,514.4$ & 188.00 \\
\hline 12 & 1983 & $57,142.1$ & $12,215.0$ & $5,949.5$ & $9,443.9$ & 230.00 \\
\hline 13 & 1984 & $63,608.1$ & $5,417.0$ & $6,418.3$ & $10,988.1$ & 320.00 \\
\hline 14 & 1985 & $72,355.4$ & $5,417.0$ & $6,804.0$ & $12,521.8$ & 295.00 \\
\hline 15 & 1986 & $73,061.9$ & $7,323.0$ & $9,313.6$ & $13,934.1$ & 662.00 \\
\hline 16 & 1987 & $10,885.1$ & $10,661.1$ & $9,993.6$ & $18,655.8$ & 1199.00 \\
\hline 17 & 1988 & $145,243.3$ & $12,383.7$ & $11,339.2$ & $24,180.0$ & 1442.00 \\
\hline 18 & 1989 & $224,796.9$ & $18,414.1$ & $10,897.6$ & $26,801.5$ & 1875.00 \\
\hline 19 & 1990 & $260,636.7$ & $30,626.8$ & $10,436.1$ & $29,651.2$ & 1673.00 \\
\hline 20 & 1991 & $324,010.0$ & $35,423.9$ & $12,243.5$ & $37,692.6$ & 1779.00 \\
\hline 21 & 1992 & $549,808.8$ & $58,640.3$ & $20,512.7$ & $54,116.8$ & 1748.00 \\
\hline 22 & 1993 & $701,472.9$ & $80,948.1$ & $66,787.0$ & $85,027.9$ & 1247.00 \\
\hline 23 & 1994 & $914,334.3$ & $85,021.8$ & $70,714.6$ & $93,966.8$ & 2721.00 \\
\hline 24 & 1995 & $914,334.3$ & $9,106,807.0$ & $119,391.6$ & $1,044,289.0$ & 7723.00 \\
\hline 25 & 1996 & $2,823,900.0$ & $96,627.2$ & $122,600.9$ & $130,858.5$ & 7723.00 \\
\hline 26 & 1997 & $2,939,500.0$ & $114,400.0$ & $128,331.9$ & $155,181.3$ & 9993.00 \\
\hline 27 & 1998 & $2,881,310.0$ & $172,100.0$ & $152,410.9$ & $194,414.2$ & 10123.00 \\
\hline 28 & 1999 & $3,352,650.0$ & $198,147.3$ & $134,189.9$ & $201,300.4$ & 9872.00 \\
\hline 29 & 2000 & $4,980,943.0$ & $290,700.1$ & $184,171.2$ & $221,219.2$ & 11141.00 \\
\hline 30 & 2001 & $5,639,860.0$ & $313,134.6$ & $172,182.5$ & $252,413.4$ & 13416.00 \\
\hline 31 & 2002 & $5,728,200.0$ & $367,112.3$ & $194,831.1$ & $268,183.3$ & 16818.00 \\
\hline 32 & 2003 & $7,180,140.0$ & $410,121.3$ & $348,761.9$ & $291,100.2$ & 13450.00 \\
\hline 33 & 2004 & $8,014,140.0$ & $513,148.0$ & $814,300.6$ & $301,891.9$ & 96819.00 \\
\hline 34 & 2005 & $11,114,239.0$ & $544,148.3$ & $948,314.3$ & $334,436.6$ & 99143.00 \\
\hline 35 & 2006 & $15,643,210.0$ & $567,492.2$ & $948,314.3$ & $355,782.5$ & 142621.00 \\
\hline 36 & 2007 & $16,102,102.0$ & $601,569.0$ & $989,053.0$ & $365,987.3$ & 154237.00 \\
\hline 37 & 2008 & $19,332,689.0$ & $643,013.1$ & $998,457,2$ & $427,351.1$ & 165389.00 \\
\hline 38 & 2009 & $20,912,546.0$ & $723,832.0$ & $1,876,342.1$ & $472,641.0$ & 189532.00 \\
\hline 39 & 2010 & $22,765,257.1$ & 987.012 .3 & $8,899,651.3$ & $543,908.0$ & 210562.00 \\
\hline 40 & 2011 & $36,543,654.70$ & $1,134,035,0$ & $9,432,753.0$ & $640,867,0$ & $20,730.6$ \\
\hline
\end{tabular}

Source; Nigerian Stock Exchange Annual Report and Account, various years; Securities And Exchange Commission Annual Report and Account; Central Bank of Nigeria Bulletin 2011, and the Federal Office of Statistics, Statistical Bulletin 


\section{Regression Result}

Table 3. Model Summary

\begin{tabular}{lllll}
\hline Model & $\mathbf{R}$ & $\mathbf{R}^{2}$ & Adjusted $\mathbf{R}^{2}$ & Std. Error of the Estimate \\
\hline 1 & $.925^{(\text {a) }}$ & .855 & .838 & 4.49560 \\
\hline
\end{tabular}

a Predictors: (Constant), D.O.H (\%), GCF (Capital Formation), Capital Market Index, FDI (Foreign Direct investment)

Table 4. ANOVA(b)

\begin{tabular}{lllllll}
\hline Model & & Sum of Squares & Df & Mean Square & F & Sig \\
\hline 1 & Regression & 3940.530 & 4 & 985.13348 & .744 & $.000(\mathrm{a})$ \\
& Residual & 666.943 & 33 & 20.210 & & \\
& Total & 4607.474 & 37 & & & \\
& & & & & & \\
\hline
\end{tabular}

a Predictors: (Constant), D.O.H (\%), GCF (Capital Formation), Capital Market Index, FDI (Foreign Direct Investment)

b Dependent Variable: GDP Nominal Value

Table 5. Coefficients (a)

\begin{tabular}{lllllll}
\hline \multirow{2}{*}{ Model } & & Un-standardized Coefficients & Standardized Coefficients & t & t & Sig \\
\cline { 3 - 7 } & & B & Std. Error & Beta & B & Std. Error \\
\hline 1 & (constant) & 1980.361 & .999 & & 1983.280 & .000 \\
& GCF (CapitalFormation) & & $-1.16 \mathrm{E}-005$ & .000 & -1.524 & -7.910 .000 \\
& FDI (ForeignDirect & $-1.19 \mathrm{E}-005$ & .000 & -.423 & -1.305 & .201 \\
& Investment) & .000 & .000 & 2.107 & 9.161 & .000 \\
& Capital Market Index & $2.32 \mathrm{E}-005$ & .000 & .099 & .342 & .735 \\
\hline
\end{tabular}

a Dependent Variable: GDP Nominal Value

\section{References}

[1] Adebiyi MA (2005). Capital Market Performance and the Nigerian Economic Growth. In: OF Oluwatayo, A Olasupo. (Eds.): Issues in Money, Finance and Economic Management. Lagos: University of Lagos. Pp13-18

[2] Aigbokan, B.K., 1995. Financial development and economic growth. Nigerian Economic and Financial Review N.E.F.R 12: $1-10$.

[3] Akinifesi, O., 1987. The role and performsances of the capital market" in adedotun philips and eddy ndewu (eds) economy policy and development in nigeria niser ibadan nigeria. NISER.

[4] Akinlo, A.E. and Ayodele F.Odusola., 2000. An alternative framework for assessing the lmpact of nigeria's naira depreciation on output and inflation. African Economic Research Consortium

[5] Akingbohungbe SS (1996). The Role of the Financial Sector in the Development of the Nigerian Economy. Paper presented at a Workshop Organized by Centre for Africa Law and Development Studies. Pp 46

[6] Al Faki M (2006). The Nigerian Capital Market and Socioeconomic Development. Paper presented at a Distinguished Faculty of Social Science Public lecture, University of Berlin, 26:9- 16.

[7] Alile, H., 1997. Government must divest. 2nd Edn.: The Business Concord of Nigeria
[8] Alile Hl (1984). The Nigerian Stock Exchange: Historical Perspectives, operations and Contributions to Economic Development, Central Bank of Nigerian Bullions 2: 6S-6Q.

[9] Alile, H., 1996. Dismantling barrier of foreign capital inflows. 14th Edn.: The Business Times Of Nigeria.

[10] Alile, H.I., 1984. The nigeria stock exchange: Historical perspective, operation and contributions to economic development. Central Bank of Nigeria Bullon, 11(65-69).

[11] Aremu et al. (2011) Journal of Research in International Business Management Vol. 1(8) pp. 258-261 September 2011

[12] Bekaert, G., 1993. Market integration and investment barrier in emerging equity market. Portfolio Investment in Development Countries, 7(466): 51-55.

[13] 13 Anyanwu JC (1993). Monetary Economics Theory, Policy and Institutions. Onitsha: Hybrid Publishers Ltd., pp. $247-27$ Structure of the Nigerian bosoms (1960-1997). Onitsha: JOANEE Educational Publishers Ltd., Pp 4S3.

[14] 14 Anyanwu (1998). Role of capital market in industrial Development in Nigeria.

[15] Aremu et al. (2011) Journal of Research in International Business Management Vol. 1(8) pp. 258-261 September 2011

[16] Asli ,Demirguc-kunt (1993). Financial and legal constrains to firm growth. J. Int. Fin. Barlett CA (2000). Helping Managers Assess the value of human capital in Global marketing Management. MNC operation from the national organization perspectives. pp 15-18. 
[17] Atoyebi Kehinde .O et al (2013) Capital Market and Economic Growth in Nigeria an Empirical Analysis. Journal of Humanities And Social Science, Volume 6, Issue 6 (Jan. Feb. 2013), PP 60-68

[18] Ben, E.A., 1999. Financial sector liberalization and capital market development in nigeria. Paper Delivered at the Department of Economic

[19] Collier, P. and J.W. Gunning, 1998. Exploring african economic performance" WPS97- 2.2 CSAE Working Paper Series. Demirguc-Kunt, A. and L. Roos, 1996. Stock market, corporate finance and economic.

[20] Demiurgic k, Detragache (1998) The consequences of overborrowing in foreign currencies. Ewan D (2009). Stock prices and exchange rate interactions in Nigeria. IUP J. Fin. Econ. IUP publication vol (2) pp 40-43

[21] davidson institute (university of michigan business school working paper series. (267)

[22] Ekundayo K (2002). The Nigeria capital market report on operational activities. CBN Annual Report account Central Bank of Nigeria Publication the capital market and its impact on the growth of the Nigerian economy. 25(1) Vol 25 pp 11

[23] Filler, R.K., Jan Hanousek., F. Nauro and Campos., 1999. Do stock market promote economic growth? "The william Hussian, M.N., K. Mlambo and T. Oshikoya, 2001. Global financial crisis: "An african perspective. Research Devision, Strategic Planning and Research Department of the Africa Development Bank, Abijan

[24] Harris T (1997). The impact of stock market operations in the Nigeria Economy. Pp 68 Levine D, Zervos M (1996) The Impact of stock market operations on the Nigeria Economy. A time series analysis. pp 14

[25] Owolabi A and Ajayi N.O. (2013) Asian Economic and Financial Review, 2013, 3(1):99-110

[26] Okereke O (2000). A critical study of the difference between capital market development and economic growth in Nigeria. SEC publication 1997, 2003. pp 2-4

[27] Oyejide T (1986). Taxation of financial Assets and Capital market Development in Nigeria AERC Research paper series. Pp 33

[28] Peter H (2000). Stock market liberalization, economic reforms and emerging market equity prices, J. Fin. Econ. 58:1-2 Peter H. (2000) Stock market liberalization, economic reforms and emerging market equity prices J. Fin Econs 58: 1-2

[29] Sule O, Momoh J (2009). Capital Market and the Nigeria industrial growth, financial system and Economic growth. A CBN publication. pp8-10

[30] Yesufu TM (1996). The Nigeria economic growth without Development. Pp 17

[31] Emenuga, C., 1998. Nigeria capital market and nigeria economic performance. A paper presented at one-day seminar organized by Nigeria Economic Society at the Institute of International Affairs.

[32] Kola, E.I., 2002. Creating a conducive environment for investment in the nigerian capital market. Opportunities in the Nigeria Capital Market for the Industrial Development of Kogi State.

[33] Levine, R. and Z. Sara, 1996. Stock market development and long-run economic growth. The World Bank review, 10(2).

[34] Malinvaud, T., 1997. Finance and economic growth: A review of theory and available evidence. Journal of Economic and Finance, 2: 231-242.

[35] Michael, P.T. and C.S. Stephen, 2003. Economic development pearson education pte ltd, indian.

[36] Nyong, M.O., 1997. Capital market development and log-run economic growth. Evidence and Analysis First Bank Review: $13-38$.

[37] Obadan, M.I., 1998. Capital market and nigeria's economic development. Nigeria Economic Society at the Institute of International Affairs.

[38] Obstfeld, M., 1994. Risk talking, global diversification and growth. American Economic Review, 84: 1310-1329.

[39] Okereke, O., 2000. Stock market and economic growth: The nigerian experience. Research Journal of finance and accounting, 3(4): 2012.

[40] Olowe, 1997. A test of strong - form efficiency of the nigerian capital market. Business system Review, 1: 16.

[41] Olowe, R.A., 2003. Financial management: Concepts analysis and capital investment. Panaf Press Ltd Lagos.

[42] Oloyede, B., 2001. Fundamental of investment analysis. Lagos: Lion press.

[43] Onoh, T.A., 2002. Analysis of capital market development. Ibadan: Ibadan University press.

[44] Onosode, G.O., 1998. The capital market and nigeria's economic development. Nigeria economic society at the institute of International Affair Lagos.

[45] Osinubi, T.S., 1998. Stock market development and long-run growth in nigeria. Unpublished M.Sc Economic Dissertation, University of Ibadan Nigeria.

[46] Oyejide, T.A., 1994. The financial system and economic growth in the context of political transition. Central Bank of Nigeria Economic and Financial Review, 32(3): 260- 267.

[47] Rostow, W.W., 1960. The process of economic growth. 2nd Edn., Ely House London W.I: Edition Oxford University Press.

[48] Samuel, C., 1996. Stock market and investment: The governance role of the market. The World Bank Review, 10(2).

[49] Soyode, A., 1990. The role of capital in economic development. Security Market Journal Nigeria, 6. 